\title{
Managing Children with Special Educational Needs and Disabilities: Pre-Service Teachers' Perceptions on Collaboration Between Professionals and Parents
}

\author{
Richard Amoako (Ph.D.) ${ }^{1} \quad$ Isaac Attia ${ }^{2 *} \quad$ Juliana Darlebnim Dinko ${ }^{3}$ \\ 1.Faculty of Educational studies, Department of Teacher Education, Kwame Nkrumah University of Science and \\ Technology, PMB, KNUST, Ghana \\ 2.Department of Education, Gambaga College of Education, Gambaga. P.O Box 33. North East Region, Ghana \\ 3.Department of Education, St. Joseph College of Education, Bechem. Ahafo Region, Ghana
}

\begin{abstract}
The paper sought to determine the perceptions Colleges of Education tutors hold on how the current curriculum helps pre-service teachers to collaborate with other professionals and parents to manage children with special educational needs and disabilities for effective inclusive education in Ghana. A descriptive survey design was adopted using a sample of 235 tutors from 13 public Colleges of Education in Ghana. The lottery method was used to select four out of the sixteen regions in Ghana and the purposive sampling technique was used to select all the Colleges within the four regions, while convenience sampling technique was used to select the actual respondents for the study. Questionnaire was used to gather the research data. Percentages and frequencies were used as statistical tools to analyse the data. The findings revealed that pre-service teachers had difficulties collaborating with other professionals and parents in managing children with special educational needs and disabilities in the inclusive classroom. It was therefore, recommended that measures that could help pre-service teachers to effectively and efficiently collaborate with parents and other professionals should be put in place.
\end{abstract}

Keywords:Collaboration, Perceptions, Inclusive Education, Pre-service teachers, Children with Special Educational Needs.

DOI: $10.7176 /$ RHSS/11-20-07

Publication date:October $31^{\text {st }} 2021$

\subsection{Introduction}

In recent years, Colleges of Education are required to ensure that pre-service teachers are competent so as to cater for the needs of an increasing range of diverse learners. According to Foreman (2001), this move is being furthered by recent international recommendations from the United Nation (UN) and the United Nation Education, Scientific and Cultural Organization (UNESCO) to include content on inclusion as part of teacher training programs. It is believed that teachers' knowledge and belief about teaching and learning are the most influential factors in success of inclusive education. Teachers are key to educational change and school improvement. Teachers do not merely deliver the curriculum; they develop, define and interpret it too (Ainscow, 1997). It is what teachers think, believe and do in the classroom that ultimately shapes the kind of learning that their students acquire in the classroom.

Many general education classroom teachers in Ghana appeared not to have the professional skills to effectively manage children with special educational needs and disabilities in the inclusive classroom. Most teachers in Ghana appeared to have limited knowledge concerning the education of children with special educational needs and therefore are unable to provide the needed support for this category of people (Amoako, Attia, Awini \& Denteh, 2021). Information gathered from other researchers including researchers' own personal experience revealed that in Ghana, general education teachers fail to provide the individual supports that children with special educational needs and disabilities require to access the general school curriculum. It is unclear whether the pre-service curriculum helps teacher-trainees on how to consult other professionals and parents in managing children with special educational needs and disabilities in inclusive classroom.

\subsection{Literature Review}

Collaboration and Support in Inclusive Setting

According to Friend and Cook (2010), collaboration is as "a style professionals select to employ based on mutual goals, parity, shared responsibility for key decisions, shared accountability for outcomes, shared resources, and the development of trust, respect, and a sense of community " Collaboration is working together with individuals or a group to achieve a common goal. This could not be more important than in education. Everyday teachers are constantly working together with other teachers, school officials, and staff to ensure success for each individual student. When it comes to special education, collaboration is the majority of what the job entails. Special education teachers must collaborate with general education teachers, school administrators, parents and guardians as well as school psychologists for a successful education of all children in the classroom. With the 
increase of children with special educational needs and disabilities included in general education classrooms, ensuring effective collaboration between general and special educators has become even more essential. Friend and Cook (2010) asserted that the literature is filled with adages about the power and desirability of teachers' working collaboratively in the inclusive classroom.

Inclusive education, as a concept, is based on the premise that no one teacher can possess all the skills needed to meet the educational needs of all the pupils in the classroom. Therefore, teachers should have support systems in place through collaboration and consultation with other professionals and parents to enable them meet every child's needs in the learning environment. Working as a team is a key to success. For some educators, especially those who do not have adequate training in teaching, learners with disabilities and special educational needs or who may be experiencing integration for the first time, the concept is frightening and intimidating (Flavell, 2001). Pre-service teachers should be prepared to discuss the problems they may experience with special needs children with other teachers and colleagues, particularly the special education professionals in the field. They should be prepared to accept different suggestions and to admit that they do not have solutions to all the problems students pose in the classroom. They must, therefore, be prepared to learn from one another. Villa and Thousand (1996) declared that collaboration enables school personnel to meet diverse student needs through shared expertise and ownership of problem definitions and solutions. This is because what happens in a successful collaboration can be stronger than what happens when teachers work alone. Hay (2003) opines that it seems obvious that inclusive education will function at its best if all parties from the mainstream and special schools are strongly involved in the process. A willingness to work together is a vital prerequisite for successful inclusive practices. Intensive involvement of educators, school leaders, special educators, parents and other professionals, heightens the expertise and leads to mutual adaptations of goals at different levels.

School-Based Support Team: A school-based support team can be instituted internally, and this support team must be co-ordinated by a member of staff, preferably someone who has received training in either life skills education, counselling or learning support (Eaton, 1996). According to White Paper 6 of The Republic of South Africa (DNE, 2001), the primary function of the school-based support team would be to support the learning and teaching process by identifying and addressing learner, educator and institutional needs. This team is made up of learners, their parents, educators and representatives from the community, organizations, and non-governmental organisations (NGO), neighbouring schools, education institutions, and other indigenous support systems (Engelbrecht, Green, Naicker \& Engelbrecht, 1999).

According to Foreman (2001), it is imperative that school-based support teams become an integral part of the education system. The teams focus should be prevention, rehabilitation, social integration and equalization of opportunities. The school-based support team is not there to remove the 'problem' learner from the classroom but acts as a support system to empower and prepare the educator to succeed within the bounds of the classroom. The purpose of this team is to support educators who are experiencing problems and are not adequately prepared to cope with special need children in the inclusive classrooms. Once the team is established the members themselves need on-going support and professional development to enable them to support the educators in their schools. Educators involved in meetings need to have "free" time and release from other responsibilities. The principles and practical aspects of the school-based support team need the full support of the staff and principal (Campher, 2003).

Support from District Level: Support from district level can enhance educators' preparedness for inclusive education. District support teams will provide the full range of education support services, such as professional development in curriculum and assessment to school-based support teams. When there is a need for more specialist advice and intervention, the district support teams (support professionals), which consist of a core of education support personnel, will be capable of offering support and advice (Engelbrecht \& Green, 2001). These teams can consist of school psychologists, special educators, guidance, counsellors, speech and language specialists, occupational therapists and even doctors and nurses (Walter-Thomas, Korinek, McLaughlin \& Williams, 2000).The main focus of the district-support team would be to ensure preparedness of educators, with a particular focus on curriculum and institutional development, and to ensure that the teaching and learning framework and environment is responsive to the full range of learning needs (DNE, 2001).

Support of Special School Educators: According to White Paper 6 of The Republic of South Africa (DNE, 2001), special schools and settings will be converted to resource centres and integrated into district support teams so that they can provide specialised professional support in curriculum, assessment and instruction to neighbouring schools. According to Bothma, Gravett and Swart (2000), services of existing structures through collaborating and teamwork must be addressed. Support and collaboration between ordinary school and special school educators can play a significant role in providing quality inclusive education in Ghana. Special school educators are encouraged to share knowledge with ordinary school educators who may otherwise not have adequate knowledge on special education at the college of education.

Research objective that guided the study was to determine perception of tutors on how the curriculum helps preservice teachers collaborate with other professionals and parent to manage children with special educational 
needs and disabilities

\subsection{Research design}

A descriptive survey design was used in conducting the study. A survey was used for the study because it enabled the researchers to ascertain respondents' perceptions on the current practices for easy description of the situation and to make intelligent recommendations to improve the situation.

\subsection{Population and sample}

The population for the study included all 38 Colleges of Education tutors out of the 46 public Colleges of Education in Ghana, totalling 1,824. However, 624 were drawn from 13 public Colleges of Education in Ashanti, Bono, Ahafo and Central Regions of Ghana. Krejcie and Morgan's (1970) table for determining sample size was used .A multi stage sampling technique was employed. These included the use of a simple random (lottery method), quota, purposive sampling and convenient sampling techniques. Four regions were selected through the lottery method out of the sixteen in Ghana, hence giving the researchers Central, Bono, Ahafo and Ashanti Regions for the study. After this stage, the quota technique was employed to assign figures to number of respondents from the selected colleges in the regions. In selecting the actual respondents for the study, the researchers used the convenient sampling technique. The use of this technique resulted from the respondents' willingness to be part of the study.

\subsection{Instrumentation}

A self-designed questionnaire was used for the study. The questionnaire was in two main sections. Section A was on personal data of respondents such as age and gender and Section B mainly focused on collaboration with professionals and parents. The instrument was pre-tested using 26 Holy Child College of Education tutors in the Western Region of Ghana. The pilot study was conducted to determine whether questionnaires would be understood by the sample to be surveyed. An introductory letter explaining the purpose of the study, soliciting co-operation of respondents and assuring them of confidentiality of information was sent to the principals of the institutions for their consent and permission. Cronbach's Alpha was used by the researchers to analyse the reliability of the instrument after the pilot test. The Cronbach's co-efficient alpha for the pre-testing was .822. In all, 235 questionnaires were administered to the respondents in the actual study. However, the researchers were able to retrieve 223 questionnaires because some tutors could not return the questionnaires.

\subsection{Findings and Discussion}

The data was analysed to reflect the research objective. Table 1 shows the frequency distributions of respondents' responses to the items.

Table 1: Perception of Tutors on how the Curriculum Helps Pre-Service Teachers to Collaborate With Other Professionals and Parent to Manage Children with Special Educational Needs and Disabilities

\begin{tabular}{|c|c|c|c|c|c|c|c|c|c|c|c|c|}
\hline \multirow[t]{2}{*}{$\mathrm{SN}$} & \multirow[t]{2}{*}{ Items } & \multicolumn{2}{|c|}{$\begin{array}{l}\text { Strongly } \\
\text { Agree }\end{array}$} & \multicolumn{2}{|c|}{ Agree } & \multicolumn{2}{|c|}{ Disagree } & \multicolumn{2}{|c|}{$\begin{array}{l}\text { Strongly } \\
\text { Disagree }\end{array}$} & \multirow[t]{2}{*}{ Total } & \multirow[t]{2}{*}{ Mean } & \multirow[t]{2}{*}{ SD } \\
\hline & & $F$ & $\%$ & $F$ & $\%$ & $F$ & $\%$ & $F$ & $\%$ & & & \\
\hline 1 & $\begin{array}{l}\text { It enables pre- } \\
\text { service teachers to } \\
\text { know how to form } \\
\text { school-based support } \\
\text { team. }\end{array}$ & 33 & 14.80 & 56 & 25.11 & 91 & 40.81 & 43 & 19.28 & 100 & 1.9531 & .35612 \\
\hline 2 & $\begin{array}{l}\text { It teaches pre- } \\
\text { service teachers how } \\
\text { to consult other } \\
\text { professionals to } \\
\text { identify and assess } \\
\text { learning difficulties } \\
\text { in inclusive } \\
\text { classroom. }\end{array}$ & 21 & 9.42 & 41 & 18.39 & 87 & 39.01 & 74 & 33.18 & 100 & $\begin{array}{l}1 . \\
7062\end{array}$ & .48259 \\
\hline 3 & $\begin{array}{l}\text { It teaches pre-service } \\
\text { teachers how to } \\
\text { collaborate with } \\
\text { other professionals } \\
\text { to plan lessons for } \\
\text { interventions. }\end{array}$ & 10 & 4.48 & 13 & 5.83 & 91 & 40.81 & 109 & 48.88 & 100 & 1.0271 & .26678 \\
\hline
\end{tabular}




\begin{tabular}{|c|c|c|c|c|c|c|c|c|c|c|c|c|}
\hline \multirow[t]{2}{*}{ SN } & \multirow[t]{2}{*}{ Items } & \multicolumn{2}{|c|}{$\begin{array}{l}\text { Strongly } \\
\text { Agree }\end{array}$} & \multicolumn{2}{|c|}{ Agree } & \multicolumn{2}{|c|}{ Disagree } & \multicolumn{2}{|c|}{$\begin{array}{l}\text { Strongly } \\
\text { Disagree }\end{array}$} & \multirow[t]{2}{*}{ Total } & \multirow[t]{2}{*}{ Mean } & \multirow[t]{2}{*}{ SD } \\
\hline & & $F$ & $\%$ & $F$ & $\%$ & $F$ & $\%$ & $F$ & $\%$ & & & \\
\hline 4 & $\begin{array}{l}\text { It teaches pre-service } \\
\text { teachers how to } \\
\text { engage other } \\
\text { professionals for } \\
\text { comprehensive } \\
\text { service delivery. }\end{array}$ & 11 & 4.93 & 32 & 9.87 & 96 & 43.05 & 94 & 42.15 & 100 & 1.3729 & .80562 \\
\hline 5 & $\begin{array}{l}\text { It teaches pre- } \\
\text { service teachers how } \\
\text { to engage other } \\
\text { professionals in } \\
\text { evaluating children } \\
\text { with } \quad \text { special } \\
\text { educational needs } \\
\text { and disabilities. }\end{array}$ & 13 & 5.83 & 29 & 13.00 & 107 & 47.98 & 74 & 33.18 & 100 & 1.1854 & .25914 \\
\hline 5 & $\begin{array}{l}\text { It teaches pre-service } \\
\text { teachers how to } \\
\text { partner with parents } \\
\text { in educating children } \\
\text { with special } \\
\text { educational needs } \\
\text { and disabilities. }\end{array}$ & 34 & 15.25 & 54 & 24.22 & 93 & 41.70 & 42 & 18.83 & 100 & 1.8542 & .51868 \\
\hline & Average & & & & & & & & & & 1.5165 & 0.448155 \\
\hline
\end{tabular}

\section{Source: Field Data 2020}

From Table 1, the mean for all the respondents' on tutors' perceptions on how the curriculum offered in Colleges of Education in Ghana prepares pre-service teachers to collaborate with other professionals and parents to manage children with special educational needs and disabilities in inclusive classroom was 1.52 . This lies in the score band of $1.6-2.5$, which implies that the respondents had a poor perception on how the curriculum offered in Colleges of Education in Ghana prepares pre-service teachers to collaborate with other professionals and parents to manage children with special educational needs and disabilities in inclusive classrooms. Sen-nefer (2013), in a study conducted in Suez in Egypt, concluded that teachers rated themselves as very poor with regard to how they collaborate with other professionals. He maintained that many parents had poor self-concept emanating from the frustrations of having children with SEN hence translating to how they deal with teachers. The teachers, in turn, in their bid to avoid the displacement of frustrations from parents, ignore or rather collaborate with them.

Another study that supports the finding of the current study is a study by Fujo (2012) in Kericho in Kenya. Fujo points out that $71.62 \%$ out of 109 teachers disagreed to all the 42 items put to them to ascertain whether the curriculum they went through in school had had any impact on how well they collaborate with other members of the multi-disciplinary team. Curtis (2013), in a study conducted in New Zealand, came out with a finding that is inconsistent with the finding of the current study. She found that a multi-disciplinary team which many professionals consider as the effective way of managing children with special educational needs in inclusive education was a common practice. He stressed that $91.34 \%$ out 375 respondents indicated that the curriculum was sufficient in addressing the challenges of children with special educational needs and disabilities.

Additionally, from the findings shown on Table 1, 33(14.80\%) of the respondents strongly agreed and $56(25.11 \%)$ agreed that the curriculum enables pre-service teachers to know how to form school-based support team. However, $91(40.81 \%)$ disagreed and $43(19.28 \%)$ strongly disagreed with the statement. This implies that pre-service teachers are not trained on how to form a school-based support team in their various schools. The work of educating children with special educational needs and disabilities in an inclusive classroom is not an easy task that one person can perform effectively alone. Therefore, for an effective implementation of inclusive education in Ghana, the general education teachers must be trained on how to bring other professionals on board to form a team so that they can share their expertise together to help children with special educational needs and disabilities develop their potentials in an inclusive classroom. It also came to light that, 21(9.42\%) of the tutors strongly agreed and $41(18.39 \%)$ agreed with the statement that pre-service teachers are taught how to consult other professional to identify and assess learning difficulties in inclusive classroom while $87(39.01 \%)$ of the tutors disagreed and 74(33.18\%) strongly disagreed with the statement. This indicates that pre-service teachers are not adequately trained on how to consult other professionals for identification and assessment of learning 
difficulties in inclusive classroom. This may contribute to the inability of the general education teachers to collaborate with parents and professionals to form school-based support teams in inclusive classroom because if teachers have not been trained on how to do consultations then how can they collaborate with other professionals and work together. Engelbrecht and Green (2001) support this assertion by noting that teachers need knowledge on how to make consultations so that when there is the need for more specialist guidance and intervention. The findings revealed that $10(4.48 \%)$ of the respondents strongly agreed and 13(5.83\%) agreed with the statement that, the curriculum for the Colleges of Education in Ghana teaches pre-service teachers how to collaborate with other professionals to plan lessons for interventions while 91(40.81\%) of them disagreed and 109(48.88) strongly disagreed. This gives a clear indication that pre-service teachers are not effectively trained on how to collaborate with other professionals when planning lessons for interventions in inclusive classroom. When teachers collaborate with other professionals during lesson planning, some vital information can be provided to the teacher, which will enable him effectively plan a programme that will meet every child's needs in the inclusive classroom. In support of this, Downing (2002) stated that sharing information and working as a collaborative team can serve to alleviate concerns and resistance of general education teachers on inclusive education.

Moreover, the findings on Table 1 shows that 11(4.93\%) of the tutors strongly agreed and $27(9.87 \%)$ agreed that the curriculum teaches pre-service teachers how to engage other professionals for comprehensive service delivery. However, 96(43.05\%) disagreed and 94(42.15\%) strongly disagreed. It is important that pre-service teachers are trained in a way that they can bring other professionals on board when providing services to children with special educational needs and disabilities. With regard to whether, the curriculum teaches pre-service teachers how to engage other professionals in evaluating children with special educational needs and disabilities $13(5.83 \%)$ of the respondents strongly agreed and $29(13.00 \%)$ agreed while $107(47.98 \%)$ disagreed and $74(33.18 \%)$ strongly disagreed. This finding contradicts the model for pre-service teacher preparation for inclusive education developed by Shumm and Vaughn (1995). According to Shumm and Vaughn (1995), collaborative planning for classes and collaborative evaluation of students can be used as a means of demonstrating how inclusive practices can be done effectively. They further recommended that teacher training institutions using the "inclusive teacher preparation model" should teach trainees how to do collaborative evaluations of student's performance. Similarly, 34(15.25\%) of the respondents strongly agreed and 54(24.22\%) agreed with the statement that the curriculum offered in the Colleges of Education in Ghana teaches pre-service teachers how to partner with parents in educating children with special educational needs and disabilities, but 93(41.70\%) of the respondents disagreed and 42(18.83\%)strongly disagreed with the statement. The finding shows that teachers do not partner with parents in educating children with special educational needs and disabilities. The role of parents in education of children with special educational needs and disabilities cannot be over emphasised. Parents can provide vital information about the child to the teacher which will serve as a baseline for the teacher.

\subsection{Conclusion and Recommendation}

The researchers finally concludes that, from the findings of the study it was revealed that prospective teachers are not trained on how to collaborate with other professionals and parents in helping children with special educational needs and disabilities to develop their potentials. Therefore, the researchers recommends that public universities and tutors of their affiliated Colleges of Education in Ghana should ensure that pre-service teachers are trained on how to do effective collaboration among parents and other professionals whose services are needed to promote and facilitate effective inclusive education.

The researchers also recommend similar studies should be conducted at public universities offering teacher training programmes since this study focused on only the College of Education Curriculum on how it equips teacher trainees on professional-parent collaboration.

\section{References}

Ainscow, M. (1997), “Towards inclusive schooling. British Journal of Special Education,” 24(1), 3-6.

Amoako, R, Attia, I., Awini, A., \& Denteh, R.(2021),“Colleges of education tutors' perceptions on modification and adaptation approaches for children with special educational needs and disabilities in Ghana". European Journal of Education Studies, 8(5), 396-409.

Bothma, M., Gravett, S., \& Swart, A. C. (2000), “The attitudes of primary school educators towards inclusive education". South African Journal of Education, 20(3), 200-204.

Campher, E. J. (2003), Educational change: A support programme for educators in an inclusive school setting. Stellenbosch: University of Stellenbosch.

Curtis, W. J. (2013), “The crusade towards inclusion. "European Journal of Special Needs Education,16(1), 61-79.

Department of National Education.(2001),“Education White Paper6: Special Needs Education”, Pretoria: 
Government Printer.

Downing, J. E. (2002), "Including students with severe and multiple disabilities in typical classroom”. Baltimore: Paul Brookes Publishing Company.

Engelbrecht, P., Green, L., Naicker, S.,\& Engelbrecht, P. (1999), "Inclusive education in action in South Africa" Pretoria: Van Schaik.

Engelbrecht, P., \& Green, L. (2001), “Promoting learner development”. Pretoria: Van Schaik.

Flavell, L. (2001), "Preparing to include special children in mainstream schools: A practical guide", London: David Futon.

Foreman, P. (2001), "Integration and inclusion in action" ,London: Harcourt Brace.

Friend, M., \& Cook, L. (2010), "Interactions: Collaborative skills for school professionals"(6 ${ }^{\text {th }}$ ed.).New York: Longman.

Fujo, T. M. (2012), "Instilling collaboration for inclusive schooling as a way of increasing access", Remedial \& Special Education, 16(3), 159-167.

Fujo, T. M. (2012)., "Instilling collaboration for inclusive schooling as a way of Increasing access", Remedial \& Special Education, 16(3), 159-167.

Hay, J. F. (2003), "Implementation of the inclusive education paradigm shift in South African education support services" ,South African Journal of Education, 23(2), 135 - 138.

Krejcie, R. V.,\& Morgan, D. W. (1970), "Determining sample size for research activities", Educational and Psychological Measurement, 30, 607- 610.

Schumm, J. S., \& Vaughn, S. (1995), "Getting ready for inclusion: Is the stage set? Learning Disabilities Research and Practice, 10(3), 169-175.

Sen-nefer, L. A. (2013), “The use of work sample to assess students' performance. "Journal of Kenya Science Education, 4(2), $65-90$.

Villa, R., A., \& Thousand, J. S. (1996), "Instilling collaboration for inclusive schooling as a way of doing business in public schools" Remedial \& Special Education, 17(3), 169-177.

Walter-Thomas, C., Korinek, L., McLaughlin, V. L., \& Williams, B. T. (2000), "Collaboration for inclusive education: Developing successful programmes",Boston: Allyn \& Bacon. 